Volume 1 Nomor 1, November 2020: h. 68 - 78

P-ISSN: 2722-4465, E-ISSN: 2746-8151

Creative Commons Attribution-NonCommercial 4.0 International

\title{
Problematika Akad Nikah Via Daring dan Penyelenggaraan Walimah Selama Masa Pandemi Covid-19
}

\section{Mahardika Putera Emas}

Fakultas Hukum Universitas Airlangga, Surabaya, Indonesia.

E-mail: emasputera@gmail.com

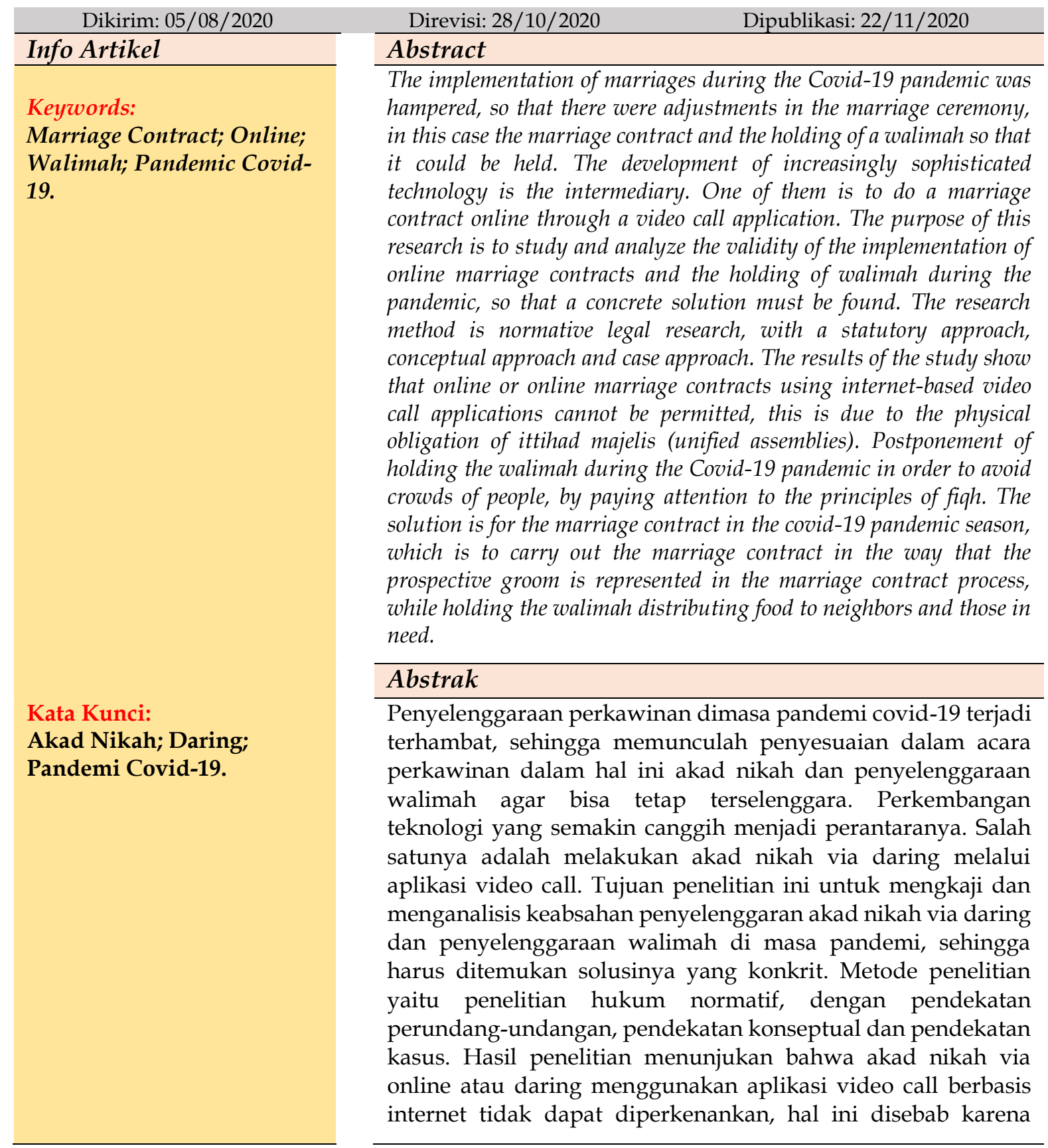


DOI:

10.47268/ballrev.v1i1.387 kewajiban ittihad majelis (bersatu majelis) secara fisik. Penundaan penyelenggarakan walimah pada saat pandemic covid-19 agar terhindar dari kerumunan masyarakat, dengan memperhatikan kaidah fiqih. Solusinya yaitu terhadap akad nikah di musim pandemic covid-19 yaitu tetap melaksanakan akad nikah dengan cara calon mempelai pria diwakilkan dalam proses akad nikah, sedangkan penyelenggaraan walimah membagikan makanan kepada tetangga dan mereka yang membutuhkan.

\section{Pendahuluan}

Pandemi yang melanda seluruh dunia pada tahun 2020, telah membawa dampak signifikan pada berbagai lini kehidupan masyarakat, tidak terkecuali pada ketentuan hukum perkawinan Islam di Indonesia. Ditetapkannya kebijakan seperti PSBB (Pembatasan Sosial Berskala Besar), physical distancing dan beragam protokol kesehatan, mengakibatkan hadirnya kesulitan dalam menjalankan beberapa ketentuan seputar hukum perkawinan Islam.

Perkawinan yang tidak dicatatkan sama saja dengan membiarkan adanya hidup bersama di luar perkawinan (Latupono, 2018: 156). Keabsahan perkawinan di Indonesia diatur pada Pasal 2 Undang-Undang Nomor 1 Tahun 1974 tentang perkawinan. Pasal 2 ayat (1) Undang-Undang Nomor 1 Tahun 1974 tentang perkawinan menyebutkan bahwa: "Perkawinan adalah sah apabila dilakukan menurut hukum masing-masing agama dan kepercayaan itu". Bagi para calon mempelai yang beragama Islam, maka tidak hanya mendasarkan pada Undang-undang nomor 1 tahun 1974 tentang perkawinan tetapi juga harus mengikuti ketentuan perkawinan atau pernikahan dalam Kompilasi Hukum Islam.

Perkembangan teknologi saat ini mengantarkan masyarakat menuju globalisasi telekomunikasi media dan informatika (Farid, 2018: 174). Pada tanggal 25 Maret 2020, telah terjadi akad nikah daring melalui aplikasi video call, atas nama pengantin pria; Kardiman bin Haeruddin dengan wali nikah istrinya (Fua, 2020). Perkawinan ini terjadi karena pengantin pria ketika itu tertahan di pelabuhan Bajoe, Kabupaten Bone, Sulawesi Selatan untuk menjalani serangkaian karantina kesehatan dalam rangka antisipasi penyebaran virus covid19. Sedangkan pengantin wanita berada di Kabupaten Kolaka, Sulawesi Tenggara. Mereka terpisah jarak sekitar $700 \mathrm{~km}$ jika menempuh perjalanan darat. Pengantin pria diharuskan menjalani protokol karantina kesehatan selama 14 hari, karena yang bersangkutan baru saja datang dari Kota Surabaya, Jawa Timur yang telah ditetapkan sebagai daerah merah terdampak covid-19. Masa karantina yang harus dijalani oleh pengantin pria mengancam penyelenggaraan akad nikah yang telah direncanakan berlangsung pada tanggal 25 Maret 2020 di kediaman pengantin wanita di Kabupaten Kolaka, Sulawesi Tenggara. Dikarenakan tidak bersedia untuk melakukan penundaan, kedua belah pihak berusaha mencari solusi agar rencana akad nikah tetap dapat berlangsung walau pasangan pengantin berada di dua tempat yang berbeda atau tidak berada dalam satu majelis secara fisik. Oleh sebab itu, dipilih saran berupa melangsungkan akad nikah menggunakan bantuan aplikasi video call agar dapat tetap menyelenggarakan akad nikah sesuai rencana, dengan pertimbangan melalui video call kedua pengantin dapat tetap dianggap satu majelis sehingga telah memenuhi rukun nikah adanya calon suami dan calon istri.

Selain itu, berdasarkan imbauan beberapa kepala daerah, sejumlah acara walimah atau resepsi dibubarkan oleh petugas untuk mencegah terjadinya kerumunan. Tindakan itu 
dilakukan dalam rangka mencegah bertambah masifnya penularan virus covid-19 di kalangan antar warga. Begitu juga terdapat kasus lain, seorang mantan Kapolsek Kembangan, harus menerima sanksi pemutasian, setelah yang bersangkutan menggelar walimah atau pesta pernikahan yang dinilai melanggar imbauan pemerintah untuk mencegah terjadinya kerumunan massa (Gunadha, 2020). Pada tanggal 19 Maret 2020, Direktorat Jenderal Bimbingan Masyarakat Islam mengeluarkan Surat Edaran Nomor 2 tahun 2020 tentang Imbauan \& Pelaksanaan Protokol Penanganan Covid 19 Pada Area Publik Di Lingkungan Direktorat Jenderal Bimbingan Masyarakat Islam Kementerian Agama. Pada bagian ketentuan huruf E angka 1 huruf d, disebutkan: "Menunda kegiatan mengumpulkan massa seperti resepsi pernikahan dan acara keagamaan untuk menghindari kerumunan". Kemudian pada tanggal 2 April 2020, Direktorat Jenderal Bimbingan Masyarakat Islam Kementerian Agama kembali mengeluarkan Surat Edaran nomor 3 tahun 2020 tentang Perubahan Atas Surat Edaran Direktur Jenderal nomor 2 tahun 2020. Pada bagian ketentuan huruf 1 point a angka 7 disebutkan: "Pelaksanaan akad nikah secara online baik melalui telepon, video call, atau penggunaan aplikasi berbasis web lainnya tidak diperkenankan".

\section{Hasil dan Pembahasan}

\subsection{Akad Nikah Via Daring}

Suatu akad nikah dapat dinyatakan sah, apabila telah memenuhi rukun-rukunnya. Berdasarkan Pasal 14 Kompilasi Hukum Islam, rukun perkawinan atau pernikahan adalah:

a) Calon Suami

b) Calon Istri

c) Wali Nikah

d) Dua Orang Saksi

e) Ijab dan Kabul

Rincian rukun tersebut selaras dengan Madzhab Syafi'i, seperti yang tercantum dalam al-Yaqut al-Nafis:" a) Suami, b) Istri, c) Wali, d) Dua Orang Saksi, \& e) Sighat (Ijab dan Kabul)" (Ahmad, 2019: 331). Masing-masing rukun tersebut memiliki syarat. Syarat pertama calon mempelai, diatur dalam Pasal 15 Kompilasi Hukum Islam : “Untuk Kemaslahatan keluarga dan rumah tangga, perkawinan hanya boleh dilakukan calon mempelai yang telah mencapai umur yang ditetapkan dalam Pasal 7 Undang-Undang No. 1 Tahun 1974 yakni calon suami sekurang-kurangnya berumur 19 tahun dan calon istri sekurang-kurangnya berumur 16 tahun." Terkait dengan umur, telah ada aturan yang merevisi aturan di atas, seperti yang tercantum dalam Pasal 1 ayat (1) Undang-Undang Nomor 16 Tahun 2019 tentang Perubahan atas Undang-undang nomor 1 tahun 1974 tentang Perkawinan, bahwa: "Perkawinan hanya diizinkan apabila pria dan wanita sudah mencapai umur 19 (sembilan belas tahun)." Syarat kedua calon mempelai, diatur dalam Pasal 16 ayat (1) Kompilasi Hukum Islam yang berbunyi: "Perkawinan didasarkan atas persetujuan calon mempelai." Syarat ketiga calon mempelai tidak mempunyai halangan perkawinan seperti yang diatur dalam Pasal 18 Kompilasi Hukum Islam, bahwa: "Bagi calon suami \& calon istri yang akan melangsungkan pernikahan tidak terdapat halangan perkawinan sebagaimana diatur dalam bab VI." Yang dimaksud halangan perkawinan pada bab VI adalah pertalian nasab, pertalian semenda, dan pertalian sesusuan.

Syarat sah wali nikah diatur dalam Pasal 20 ayat (1) Kompilasi Hukum Islam, bahwa: "Yang bertindak sebagai wali nikah ialah seorang laki-laki yang memenuhi syarat hukum 
Islam muslim, aqil, dan baligh." Kemudian diklasifikasikan pada Pasal 20 ayat (2) yang berbunyi : "Wali nikah terdiri ; a. Wali Nasab, b. Wali Hakim".

Syarat sah saksi nikah diatur pada Pasal 25 Kompilasi Hukum Islam yang berbunyi: "Yang dapat ditunjuk sebagai saksi dalam akad nikah ialah seorang laki-laki muslim yang adil, aqil baligh, tidak terganggu ingatan, dan tidak tuna rungu atau tuli." Lalu juga diatur dalam Pasal 26, bahwa: "Saksi harus hadir dan menyaksikan secara langsung akad nikah serta menandatangani Akta Nikah pada waktu dan di tempat akad nikah dilangsungkan."

Kemudian terkait syarat ijab dan kabul, diatur pada Pasal 27 Kompilasi Hukum Islam yang berbunyi: "Ijab dan Kabul antara wali dan calon mempelai pria harus jelas beruntun dan tidak berselang waktu." Lalu diatur pula pada Pasal 29 ayat (1) - (3), bahwa:

(1) Yang berhak mengucapkan kabul ialah calon mempelai pria secara pribadi

(2) Dalam hal-hal tertentu ucapan kabul nikah dapat diwakilkan kepada pria lain dengan ketentuan calon mempelai pria memberi kuasa yang tegas secara tertulis bahwa penerimaan wakil atas akad nikah itu adalah untuk mempelai pria

(3) Dalam hal calon mempelai wanita atau wali keberatan calon mempelai pria diwakili, maka akad nikah tidak boleh dilangsungkan

Seluruh rukun dan syarat di atas harus dipenuhi agar akad nikah dinyatakan sah dan kedua calon mempelai resmi menjadi pasangan suami dan istri. Namun, perkembangan teknologi telekomunikasi yang didukung oleh jaringan internet, memunculkan suatu kreatifitas pada pasangan calon mempelai yang hendak menikah tetapi terkendala oleh jarak yang terpisah jauh. Keduanya sulit hadir dalam satu majelis yang sama karena hambatan ekonomi maupun aktifitas dan pekerjaan yang tidak bisa ditinggalkan. Kreatifitas yang dimaksud adalah menggunakan bantuan sarana aplikasi video call yang berbasis internet dalam prosesi ijab dan kabul sebagai pelaksanaan salah satu rukun akad nikah. Jika mengacu pada Kompilasi Hukum Islam, sebenarnya solusi dari masalah tersebut dapat diatasi mengacu pada ketentuan Pasal 29 ayat (2) seperti yang telah disebut di atas, yakni calon mempelai pria memberikan kuasa yang tegas secara tertulis kepada pria lain bahwa penerimaan wakil atas akad nikah itu adalah untuk mempelai pria. Metode ini disebut dengan metode tawkil (Muhajir, 2018: 11). Hanya saja disebabkan perkembangan teknologi telekomunikasi, metode ini tidak ditempuh karena dinilai bahwa masalah keterpisahan jarak telah dapat diatasi dengan aplikasi video call yang semakin marak, mudah diakses bahkan tanpa biaya dan dapat langsung menyambungkan antara wali nikah dengan calon mempelai pria untuk melaksanakan ijab dan kabul secara real time. Berbeda halnya dengan kasus lama akad nikah melalui telepon antara Drs. Ario Sutarto dengan wali nikah atas nama Prof. Dr. H. Baharuddin Harahap, sebagaimana telah ditetapkan sah oleh Pengadilan Agama Jakarta Selatan dalam Penetapan Nomor 1751/p/1989. Akad nikah melalui sambungan telepon tersebut masih sangat riskan terjadi keraguan atau bahkan penipuan. Sehingga penetapan tersebut mengundang reaksi kontra dari para ulama dan cendekiawan, karena dinilai sarana sambungan telepon masih belum bisa memenuhi kehadiran calon mempelai pria sebagai salah satu rukun nikah. Sedangkan pada kasus akad nikah melalui video call, pro dan kontra lebih tampak. Argumen kalangan yang pro atau memandang sah akad nikah melalui video call menyatakan : (Burhanuddin, 2017: 72)

"Hukum akad nikah melalui video call menurut Undang-undang perkawinan dan Kompilasi Hukum Islam di Indonesia bahwa pelaksanaan ijab kabul melalui video call dalam pelaksanaannya sudah memenuhi syarat dan rukun perkawinan serta tidak bertentangan dengan kompilasi hukum Islam, maka perkawinan tersebut sudah sah. Hal ini dikuatkan dengan ketentuan pasal 27 sampai dengan 29 Kompilasi Hukum 
Islam antara lain tidak berselang waktu dan diucapkan langsung oleh mempelai lakilaki melalui video call, kemudian semua aspek perkawinan terpenuhi antara lain rukun, syarat sah, syarat-syarat perkawinan.

Selaras dengan argumen di atas, terdapat juga fatwa dari Majelis Tarjih \& Tajdid Muhammadiyah, yaitu (Tarjih \& Tajdid, 2016):

"Para ulama imam madzhab sepakat tentang sahnya akad ijab dan qabul yang dilakukan oleh dua pihak yang berjauhan melalui sarana surat atau utusan. Misalnya ijab dan qabul dilakukan melalui surat atau utusan dari wali yang dikirimkan kepada calon suami. Jika akad ijab dan qabul melalui surat, yang dimaksud dengan majlis akad yaitu tempat suami membaca surat yang berisi ijab dari wali di hadapan para saksi, dan jika calon suami setelah membaca surat yang berisi ijab dari wali segera mengucapkan qabul, maka akad dipandang dilakukan dalam satu majlis. Jika akad ijab dan qabul melalui utusan, yang dimaksud dengan majlis akad yaitu tempat utusan menyampaikan ijab dari wali pada calon suami di hadapan para saksi, dan jika setelah utusan menyampaikan ijab dari wali, calon suami segera mengucapkan qabul, maka akad dipandang telah dilakukan dalam satu majlis. Pada zaman dahulu, akad antara dua pihak yang berjauhan hanya terbatas melalui alat komunikasi surat atau utusan. Dewasa ini, alat komunikasi berkembang pesat dan jauh lebih canggih. Seseorang dapat berkomunikasi melalui internet, telepon, atau melalui tele-conference secara langsung dari dua tempat yang berjauhan. Alat komunikasi telepon atau hand phone (HP), dahulu hanya bisa dipergunakan untuk berkomunikasi lewat suara (berbicara) dan Short Massage Service (SMS: pesan singkat tertulis). Saat ini teknologi HP semakin canggih, di antaranya adalah fasilitas jaringan 3G. 3G atau third generation adalah istilah yang digunakan untuk sistem komunikasi mobile (hand phone) generasi selanjutnya. Sistem ini akan memberikan pelayanan yang lebih baik dari apa yang ada sekarang, yaitu pelayanan suara, teks dan data. Jasa layanan yang diberikan oleh 3G ini adalah jasa pelayanan video, akses ke multimedia dan lain-lain. Dengan fasilitas ini, yakni dengan video call, seseorang dapat berkomunikasi langsung lewat suara dan melihat gambar lawan bicara. Oleh sebab itulah, jika akad ijab dan qabul melalui surat atau utusan disepakati kebolehannya oleh ulama madzhab, maka akad ijab dan qabul menggunakan fasilitas jaringan 3G, yakni melalui video call lebih layak untuk dibolehkan. Dengan surat atau utusan sebenarnya ada jarak waktu antara ijab dari wali dengan qabul dari calon suami. Sungguhpun demikian, akad melalui surat dan utusan masih dianggap satu waktu (satu majlis). Sedangkan melalui video call, akad ijab dan qabul benar-benar dilakukan dalam satu waktu. Dalam akad ijab qabul melalui surat atau utusan, pihak pertama yakni wali tidak mengetahui langsung terhadap pernyataan qabul dari pihak calon suami. Sedangkan melalui video call, lebih baik dari itu, yakni pihak wali dapat mengetahui secara langsung (baik mendengar suara maupun melihat gambar) pernyataan qabul dari pihak calon suami, demikian pula sebaliknya. Kelebihan video call yang lain, para pihak yakni wali dan calon suami mengetahui secara pasti kalau yang melakukan akad ijab dan qabul betul-betul pihakpihak terkait. Sedangkan melalui surat atau utusan, bisa saja terjadi pemalsuan. Dengan demikian akad ijab dan qabul melalui video call sah secara syar'i, dengan catatan memenuhi syarat-syarat akad ijab dan qabul yang lain, serta memenuhi rukunrukun dan syarat-syarat sah nikah yang lain. Apabila akad ijab dan qabul melalui video call sah antara wali dengan calon suami, maka sah juga untuk akad tawkil (mewakilkan) dari pihak wali kepada wakil jika wali mewakilkan akad 
nikah pada orang lain. Bahkan sah juga akad ijab dan qabul melalui video call antara wakil dengan mempelai pria".

Terdapat pula argumen pro dari situs www.islamqa.info yang dikelola oleh Syaikh Muhammad Shalih al-Munajjid, bahwa: "Hence the most correct view with regard to this matter is that it is permissible to do the marriage contract over the phone or Internet, if there is no danger of tampering, the identity of the husband and wali is proven, and the two witnesses can hear the proposal and acceptance" (Al-Munajjid, 2013).

Sedangkan untuk argumen kontra, terdapat fatwa dari Majma' al Fiqh al Islami (Islamic Figh Council) yang berpusat di kota Mekkah, Kerajaan Saudi Arabia, yakni: "The guidelines mentioned above (that is permissible to do contracts via modern means of communication) do not apply to marriage contract, because of stipulation that witnesses be present in that case" (Al-Munajjid, 2013).

Kemudian, fatwa dari Lembaga Bahtsul Masail Nadlatul Ulama, yang menyatakan:

“Menurut NU akad nikah tersebut [melalui internet] tidak sah, karena sudah didasarkan atas berbagai pertimbangan, karena pernikahan melalui alat bantu elektronik tidak bisa melakukan akad secara langsung. Langsung dimaksud adalah keterlibatan wali, dan pengantin pria. Kedua, karen saksi tidak melihat \& mendengar suara secara langsung pelaksanaan akad dan saksi hadir di majelis akad. Di dalam akad nikah disyaratkan lafaz yang (jelas). Pernikahan melalui alat elektronik ini tergolong (samar-samar)" (Burhanuddin, 2017: 13).

Berdasarkan argumen pro maupun kontra di atas, terdapat perbedaan pandangan mengenai ittihad majelis (bersatu majelis) pada pelaksanaan akad nikah. Argumen pro memandang yang dimaksud ittihad majelis ialah bahwa ijab dan qabul harus ada kesinambungan yang berarti tidak boleh ada perbuatan maupun ucapan lain yang muncul di antara ijab dan qabul, dan pihak yang berakad tidak disyaratkan satu tempat. Sedangkan argumen kontra berpandangan bahwa akad nikah harus dilaksanakan dengan bersatu majelis secara fisik dalam satu tempat yang sama, bukan saja untuk menjamin kesinambungan ijab \& qabul, tapi sangat terkait dengan tugas dua orang saksi yang harus melihat dengan mata kepalanya bahwa ijab dan qabul benar-benar diucapkan oleh kedua orang yang melakukan (Faizal et al., 2019: 53-54), dalam kaitannya mengenai masalah ittihad majelis ini, prinsip kepastian harus dikedepankan. Hal tersebut karena perkawinan dalam ajaran Islam mengandung nilai kepastian hukum yang berarti perkawinan harus dilaksanakan dengan memenuhi sejumlah persyaratan tertentu, baik yang menyangkut kedua belah pihak maupun yang berhubungan dengan pelaksanaan perkawinan itu sendiri (Kaharuddin, 2015: 100). Ijab dan qabul melalui sarana video call yang praktiknya dilakukan antara wali nikah dengan calon mempelai pria tidak dapat dilakukan, sebab cara semacam itu masih menimbulkan ketidakpastian hukum atau kesamaran. Ketidakpastian ini disebabkan atas sejumlah ketentuan dan persoalan yaitu:

1) Nikah adalah perkara ibadah

Pada dasarnya, pernikahan adalah termasuk ibadah, maka dalam pelaksanaannya harus sesuai dengan tuntunan Al-Qur'an dan Sunnah Nabi Muhammad SAW, berdasarkan kaidah "hukum asal ibadah adalah haram, hingga ada dalilnya". Akad nikah dalam kondisi wali nikah dengan calon mempelai pria berjauhan, telah terjadi pada masa Rasulullah SAW yang beliau jalani sendiri ketika perkawinannya dengan Ummu Habibah yang bernama asli Ramlah binti Abu Sufyan bin Harb. Ketika itu Rasulullah SAW yang berada di Madinah terpisah dengan Ummu Habibah selaku 
calon mempelai perempuan yang berada di Habasyah. Oleh karena itu, Rasulullah SAW melakukan tawkil atau melaksanakan akad wakalah dengan Raja Habasyah yang bernama Najasyi dengan mengutus Amr bin Umaiyyah Adh-Dhamri untuk membawa surat permohonan perwakilan kepada Najasyi. Isi surat itu adalah permohonan kepada Najasyi untuk mewakili Rasulullah SAW sebagai calon mempelai pria di hadapan wali nikah yang ketika itu diemban oleh seorang sahabat yang bernama Khalid bin Sa'id bin al-Ash (Hisyam, 2018: 633).

2) Persyaratan al-Mu'ayanah

Pengertiannya adalah dapat dilihat dengan mata kepala. Keharusan bersatu majelis tidak hanya terkait untuk menjaga kesinambungan antara ijab dan qabul, namun juga terkait erat dengan tugas dua orang saksi untuk menyaksikan secara langsung jalannya proses akad nikah. Dengan begitu, segala potensi ketidakpastian dapat diminimalisir oleh dua orang saksi tersebut. Terlebih konsep dari saksi adalah seseorang yang mengalami suatu peristiwa secara langsung, seperti ketentuan Pasal 26 Kompilasi Hukum Islam yang berbunyi: "Saksi harus hadir dan menyaksikan secara langsung akad nikah serta menandatangani akta nikah pada waktu dan tempat akad nikah dilangsungkan".

3) Peluang manipulasi

Perkembangan teknologi yang sangat pesat, seringkali membuat hal-hal yang pada suatu zaman masih mustahil berubah menjadi nyata pada zaman setelahnya. Seperti halnya teknologi yang saat ini mulai jadi bahan pembicaraan dalam hal manipulasi wajah, yakni yang disebut "deepfakes"(Toews, 2020). Teknologi berbasis software ini mampu merekayasa wajah seseorang sehingga berubah menjadi wajah orang lain yang diinginkan. Bahkan dalam perkembangannya, teknologi ini mampu dilakukan secara real time ketika berkomunikasi menggunakan aplikasi teleconference atau video call berbasis internet. Kecanggihan tersebut dapat membuat lawan bicara tidak menyadari bahwa lawan bicaranya adalah seseorang yang berbeda dengan yang dirinya kira atau memiliki wajah yang berbeda dengan yang diketahui sebelumnya, seperti yang dapat dilakukan oleh aplikasi Looksery (O'Callaghan, 2014) dan Avatarify (Kasana, 2020). Manipulasi dapat lebih sulit disadari jika pelaku juga memiliki kemampuan imitasi suara. Adanya kecanggihan semacam itu dapat membuka potensi penipuan atau kejahatan lainnya jika wali nikah melakukan akad nikah dengan calon mempelai pria melalui sambungan video call. Dua saksi pun yang turut menyaksikan melalui layar kaca gawai maupun layar proyektor belum tentu dapat mendeteksi potensi manipulasi dan imitasi deepfakes tersebut.

4) Ketimpangan konektivitias

Masih adanya ketimpangan konektivitas antar daerah di Indonesia (Dewi, 2020), dapat menimbulkan potensi gangguan sinyal yang tidak stabil ketika akad nikah dilakukan via daring. Jika hal tersebut terjadi maka kesinambungan ijab dan qabul menjadi sulit terlaksana, sehingga proses akad nikah terpaksa ditunda atau terbuka peluang peremehan rukun nikah dari pihak yang bersangkutan agar akad nikah dapat tetap terlaksana \& dinyatakan sah.

5) Terdapat ketentuan dari pemerintah yang memiliki derajat seperti qanun

Peraturan yang dimaksud adalah ketentuan huruf 1 point a angka 7 Surat Edaran Direktorat Jenderal Bimbingan Masyarakat Islam Kementerian Agama nomor 3 Tahun 2020 yang berbunyi: "Pelaksanaan akad nikah secara online baik melalui 
telepon, video call, atau penggunaan aplikasi berbasis web lainnya tidak diperkenankan". Ketentuan tersebut memiliki derajat atau sifat seperti halnya qanun dalam khazanah perundang-undangan Islam, yakni pengertiannya adalah: "Kumpulan dari ketentuan yang menjadi hukum atau mengatur perilaku individu pada masyarakat, dimana ketentuan itu memaksa individu untuk mematuhinya dengan kekuatan tatkala ditetapkan" (Sarwat, 2017: 611)

Berdasarkan beberapa uraian di atas, penulis cenderung mendukung pandangan kontra akad nikah via daring, karena lebih selaras dengan prinsip kepastian dan prinsip kehatihatian.

\subsection{Walimah di Masa Pandemi Covid-19}

Pesta perkawinan atau walimah menjadi salah satu klaster baru penularan covid-19. Seperti kasus yang terjadi di Kota Semarang pada 16 Juni 2020 (Saputra, 2020). Hal tersebut terjadi karena warga nekat menyelenggarakannya di tengah masa pandemi dan diperparah dengan kurangnya kesadaran untuk mematuhi protokol kesehatan. Mafsadat yang timbul akhirnya lebih besar dari maslahat yang ingin digapai. Hukum asal dari menyelenggarakan walimah bukan wajib melainkan sunnah mu'akkad (sunnah yang sangat dianjurkan). Konsekuensinya ialah walaupun sangat dianjurkan untuk diadakan, namun tidak berdosa jika walimah diputuskan untuk ditiadakan, terlebih jika terdapat keadaan darurat seperti pandemi. Alasan mayoritas ulama menghukumi walimah pada derajar sunnah adalah karena (Azizah, 2018: 7-8):

" sebab adanya walimah adalah akad nikah, sedangkan akad nikah atau pernikahan itu sendiri hukumnya tidak wajib. Maka walimah yang merupakan bagian dari pernikahan itu sendiri hukumnya tidak wajib. Kalaupun seandainya hukumnya wajib maka akan disebutkan kadarnya seperti disebutkannya kadar zakat dan kafarat. Dan ketika seseorang kesulitan dalam melaksanakannya akan ada badal atau penggantinya. Seperti kafarat yang bisa diganti dengan puasa ketika merasa kesulitan".

Kemudian, juga perlu dipraktikkan kaidah fiqih dasar adh-Dhararu yuzalu (Bahaya harus dihilangkan). Pengertiannya secara lebih luas ialah: "Kemudharatan hendaknya wajib dihindari sedapat mungkin sebelum terjadi, karena "mencegah" lebih baik daripada "mengobati". Harus ada usaha menghindari mudharat itu semampunya secara keseluruhan jika memang mungkin dan jika pun tidak dapat seluruhnya, maka sampai pada batas yang mungkin dilakukan (Thalhah, 2014: 71)."

Pelaksanaan kaidah di atas sudah selaras dengan ketentuan yang dirilis pada bagian ketentuan angka 1 huruf d Surat Edaran Direktorat Jenderal Bimbingan Masyarakat Islam Kementerian Agama Nomor 2 tahun 2020 tentang Imbauan dan Pelaksanaan Protokol Penanganan Covid-19 pada Area Publik di Lingkungan Direktorat Jenderal Bimbingan Masyarakat Islam, bahwa: "Menunda kegiatan mengumpulkan massa seperti resepsi pernikahan dan acara keagamaan untuk menghindari kerumunan."

\subsection{Solusi Terhadap Akad Nikah Via Daring dan Walimah di Masa Pandemi Covid-19}

Solusi dari problematika pelaksanaan akad nikah di masa pandemi bagi pasangan yang terpisah jarak lalu wali nikah juga berada di tempat calon mempelai perempuan adalah dengan mengupayakan tawkil yang dilakukan oleh calon mempelai pria kepada seseorang yang dipercaya untuk mewakilinya melaksanakan akad nikah dengan wali nikah. Disebutkan bahwa: “...kehadiran suami dalam sebuah akad nikah, tidak menjadi syarat, karena calon suami boleh mewakilkan akad nikah kepada orang lain yang ditunjuknya 
dengan memenuhi semua ketentuan dan syaratnya (Sarwat, 2019: 93)." Hal ini sesuai dengan ketentuan pada Pasal 29 ayat (2) Kompilasi Hukum Islam yang berbunyi: "Dalam hal-hal tertentu ucapan kabul nikah dapat diwakilkan kepada pria lain dengan ketentuan calon mempelai pria memberi kuasa yang tegas secara tertulis bahwa penerimaan wakil atas akad nikah itu adalah untuk mempelai pria."

Sedangkan, untuk penyelenggaraan walimah atau pesta perkawinan dapat ditunda terlebih dahulu karena bukan merupakan rukun nikah serta hukum penyelenggarannya pun juga tidak wajib dalam hal ini ialah sunnah mua'akkad. Tidak ada konsekuensi kerusakan pada akad nikah maupun dosa yang diterima karna tidak menyelenggarakannya. Terlebih telah ada imbauan penundaan walimah dari Kementerian Agama yang tercantum pada bagian ketentuan angka 1 huruf d Surat Edaran Direktorat Jenderal Bimbingan Masyarakat Islam Kementerian Agama Nomor 2 tahun 2020 tentang Imbauan dan Pelaksanaan Protokol Penanganan Covid-19 pada Area Publik di Lingkungan Direktorat Jenderal Bimbingan Masyarakat Islam. Jika memang tetap ingin menyelenggarakan walimah [dalam arti menghidangkan makanan kepada orang-orang seperti pengertian secara istilah dari walimah yakni : “...makanan yang dihidangkan untuk menggambarkan kegembiraan dalam acara pernikahan dan adanya perpindahan kepemilikan. Maksud dari perpindahan kepemilikan adalah perpindahan tanggung jawab seorang wanita dari walinya ke suaminya"(Azizah, 2018: 6), maka dapat disiasati dengan mengirimkan walimah hanya kepada tetangga sekitar dan kepada mereka yang membutuhkan seperti seruan dalam hadits shahih riwayat Imam Muslim yang berbunyi: “Dari Abu Hurairah r.a., bahwasanya ia dulu berkata, 'Seburuk-buruk makanan adalah makanan pesta pernikahan yang orang-orang kaya diundang untuk memakannya, sementara orang-orang miskin tidak diundang. Siapa yang tidak memenuhi undangan, berarti ia telah durhaka kepada Allah dan Rasul-Nya' (A1Bugha et al., 2012: 689)."

\section{Kesimpulan}

Akad nikah via online atau daring menggunakan aplikasi video call berbasis internet tidak dapat diperkenankan atas sebab keharusan ittihad majelis (bersatu majelis) secara fisik. Sedangkan perluasan makna ittihad majelis yang dikatakan dapat terealisasi secara daring mengandung kelemahan yang beresiko besar karena sejumlah faktor yakni : Nikah adalah ibadah, persyaratan al-Mu'ayanah, peluang manipulasi, ketimpangan konektivitas, dan terdapat ketentuan pemerintah yang memiliki derajat seperti qanun. Hukum menyelenggarakan walimah adalah sunnah mu'akkad sehingga tidak masalah jika tidak diselenggarakan, terlebih di masa pandemi yang harus menghindari terjadinya kerumunan masyarakat. Maka dari itu sebaiknya ditunda dahulu dengan memerhatikan kaidah fiqih adh-Dhararu yuzalu (bahaya harus dihilangkan) dan imbauan penundaan dari Kementerian Agama.

Solusi dari dua calon mempelai yang terpisah jarak dan sulit bertemu karena terhalang kebijakan serta protokol kesehatan yang terkait dengan pandemi, dapat tetap melaksanakan akad nikah dengan cara calon mempelai pria melakukan tawkil kepada orang yang ia percaya untuk mewakilkan dirinya sebagai calon mempelai pria dalam prosesi akad nikah bersama wali nikah. Cara ini sesuai dengan yang pernah ditempuh oleh Rasulullah SAW dan sesuai dengan ketentuan dalam Kompilasi Hukum Islam. Sedangkan solusi untuk penyelenggaraan walimah adalah dengan mengirimkan hidangan makanan hanya kepada tetangga sekitar dan kepada mereka yang membutuhkan. 


\section{Daftar Referensi}

\section{Jurnal}

Faizal, B., Fathur, M., \& Handar, S. B. (2019). Praktik Pencatatan Ijab Qabul Via Online dalam Proses Akad Nikah Di Makassar. PUSAKA: Jurnal Khazanah Keagamaan, 7(1), 49-62. https://doi.org/10.31969/pusaka.v7i1.241

Farid, M. (2018). Nikah Online dalam Perspektif Hukum. Jurisprudentie : Jurusan Ilmu Hukum Fakultas Syariah Dan Hukum, 5(1), 174-189. https:// doi.org/10.24252/jurisprudentie.v5i2.5437

Latupono, B. (2018). Pencatatan Perkawinan Di Indonesia Dikaitkan Dengan Good Governance. SASI, 24(2), 150-160. https:// doi.org/10.47268/sasi.v24i2.129

Muhajir. (2018). Studi Analisis Putusan Pengadilan Agama Jakarta Selatan No. 1751/p/1989 tentang Perkawinan Melalui Telepon. Al-Qadha, 5(1), 9-19. https:// doi.org/10.32505/qadha.v5i1.956

Thalhah. (2014). Kaidah Fiqhiyah Furu'iyah: Penerapannya pada Isu Kontemporer. Tahkim: Jurnal Hukum Dan Syariah, 10(1), 67-88. https:/ / doi.org/10.33477/thk.v10i1.64

Buku

Ahmad, I. B. U. A.-S. (2019). Al-Yaqut Al-Nafis (Ringkasan Fikih Madzhab Syafi'i), (Terjemahan Ahmad Dzulfikar). Solo: Pustaka Arafah.

Al-Bugha, M., Al-Khan, M., \& Al-Syurbaji, A. (2012). Al-Fiqh al-Manhaji 'ala al-Madzhab alImam asy-Syafi'i (Jilid 1). (Terjemahan Misran), Yogyakarta: Darul Uswah.

Azizah, N. (2018). Haruskah ada Walimah. Jakarta: Rumah Fiqih Publishing.

Hisyam, I. (2018). As-Sirah an-Nabawiyah li Ibni Hisyam (Jilid II). (Terjemahan Fadhli Bahri), Bekasi: Darul Falah.

Kaharuddin. (2015). Nilai-Nilai Filosofi Perkawinan. Jakarta: Mitra Wacana Media.

Sarwat, A. (2017). Seri Fiqih Kehidupan: Muqaddimah. Jakarta: Rumah Fiqih Publishing.

Sarwat, A. (2019). Ensiklopedia Fikih Indonesia 8: Pernikahan. Jakarta: Gramedia Pustaka Utama.

\section{Online/World Wide Web}

Al-Munajjid, M. S. (2013). Ruling on Doing The Marriage Contract over The Phone or Internet. Islam Question \& Answer. https://islamqa.info/en/answers/105531/ruling-ondoing-the-marriage-contract-over-the-phone-or-internet

Dewi, N. S. (2020). Riset : Sinyal Jaringan Seluler Masih Belum Merata di Indonesia. Digination.Id. https:// www.digination.id/read/016133/riset-sinyal-jaringan-seluler-masih-belummerata-di-indonesia

Fua, A. A. (2020). Viral Sepasang Pengantin Menikah via Video Call gara-gara Virus Corona. Liputan6.Com. https://www.liputan6.com/regional/read/4211432/viral-sepasangpengantin-menikah-via-video-call-gara-gara-virus-corona

Gunadha, R. (2020). Pesta Nikah saat Corona, Publik Protes Kapolsek Kembangan Cuma Dimutasi. Suara.Com. https://www.suara.com/news/2020/04/02/140835/pesta-nikah-saatcorona-publik-protes-kapolsek-kembangan-cuma-dimutasi 
Kasana, M. (2020). This Open-Source Program Lets You Run Deepfakes on Live Video Calls. Input. https:// www.inputmag.com/tech/open-source-program-will-let-you-run-deepfakeson-live-video-calls

Muhajir. (2018). Studi Analisis Putusan Pengadilan Agama Jakarta Selatan No. 1751/p/1989 tentang Perkawinan Melalui Telepon. Al-Qadha, 5(1), 9-19. https:// doi.org/10.32505/qadha.v5i1.956

O'Callaghan, J. (2014). Why the WRONG face? App uses real-time facial tracking to transform your appearance during live video calls. Mail Online. https:// www.dailymail.co.uk/sciencetech/article-2652997/Why-WRONG-face-Appuses-real-time-facial-tracking-transform-appearance-video-calls.html

Saputra, I. Y. (2020). Pernikahan Jadi Klaster Baru Penularan Covid-19 di Semarang, Ini Kata Walikota. Solopos.Com. https://www.solopos.com/pernikahan-jadi-klaster-barupenularan-covid-19-di-semarang-ini-kata-wali-kota-1067153

Tarjih, M., \& Tajdid. (2016). Akad Nikah Via Vidio Call. Muhammadiyah.or.Id. http://m.muhammadiyah.or.id/id/artikel-akad-nikah-via-video-call-detail-624.html

Toews, R. (2020). Deepfakes are going to Wreak Havoc on Society. We are Not Prepared. Forbes.Com. https://www.forbes.com/sites/robtoews/2020/05/25/deepfakes-aregoing-to-wreak-havoc-on-society-we-are-not-prepared/?sh=5ae2c15d7494

\section{Skripsi}

Burhanuddin, M. (2017). Akad Nikah Melalui Video Call dalam Tinjauan Undang-Undang Perkawinan dan Hukum Islam di Indonesia. Skripsi: Universitas Alauddin Makassar. 